\title{
Microvessel Density as a Prognostic Factor in Ovarian Cancer: a Systematic Review and Meta-analysis
}

\author{
Lei He, Qiao Wang, Xia Zhao*
}

\begin{abstract}
Background: The prognostic value of microvessel density (MVD), reflecting angiogenesis, detected in ovarian cancer is currently controversial. Here we performed a meta-analysis of all relevant eligible studies. Materials and Methods: A comprehensive search of online PubMed, Medline, EMBASE and Sciencedirect was performed to identify all related articles. The search strategy was designed as 'microvessel density', 'ovarian cancer', 'ovarian neoplasm', 'CD34' and 'angiogenesis'. Results: The studies were categorized by author/year, number of patients, FIGO stage, histology, cutoff value for microvessel density, types of survival analysis, methods of hazard rations (HR) estimation, HR and its $95 \%$ confidence interval (CI). Combined hazard ratios suggested that high MVD was associated with poor overall survival (OS) and progression-free survival (PFS), with HR and 95\% CIs of $1.84(1.33-2.35)$ and $1.36(1.06-1.66)$, respectively. Subgroup analysis showed that high MVD detected by CD34 was relevant for OS [HR=1.67 (1.36-2.35)], but not MVD detected with other antibodies [HR=2.11 (0.90-3.31)]. Another subgroup analysis indicated that high MVD in patients without pre-chemotherapy, but not with prechemotherapy, was associated with $\mathrm{OS}[\mathrm{HR}=1.88(1.59-2.18$ and $\mathrm{HR}=1.70(-0.18-3.59)]$. Conclusions: The OS and PFS with high MVD were significant poorer than with low MVD in ovarian cancer patients. However, high MVD detected by CD34 seems to be more associated with survival for patients without pre-chemotherapy.
\end{abstract}

Keywords: Microvessel density - survival - ovarian cancer - chemotherapy - meta-analysis - CD34

Asian Pac J Cancer Prev, 16 (3), 869-874

\section{Introduction}

Ovarian cancer, as an infamous "silent killer", is one of the most lethal gynecological neoplasms in women. Owing to development of surgery and chemotherapy with empirically optimized combinations of conventional agents, survival rate of ovarian cancer remains approximately 30\% (Bast et al., 2009). Independent prognostic factors such as International Federation of Gynecology and Obstetrics (FIGO) stage, residual disease after surgery, histology and lymph node status allow a better understanding of the natural history and process of ovarian cancer and the classification of homogeneous populations with a similar outcome profile. However, these prognostic factors insufficiently predict individual clinical outcome. Therefore, to optimize clinical care, putative molecular marker such as serum CA 125 must be identified.

Angiogenesis has attracted an enormous surge in interest over the past twenty years. Undoubtedly, the hypothesis that targeting angiogenesis could be a promise strategy to overcome cancer has been extraordinary in inspiring scientists to participate in this field (Folkman, 1971). Angiogenesis is implicated in pathogenesis, progression and metastasis of malignancies. Without vessels, tumor can't exceed $1-2 \mathrm{~mm}$ or metastasize to distant organs. Vessels in an embryo are derived form in situ differentiation of undifferentiated precursor cells to vascular endothelial cells (Risau, 1997). Subsequently, this primeval structure expands by sprouting of capillaries from pre-existing vessels or intussusception, in which interstitial tissue such as tumor cells are integrated into the lumen of pre-existing vessels (Carmeliet, 2000). In addition, tumor cells next to existing vessels have an ability to form a perivascular cuff (Yancopoulos et al., 2000). It is still a controversial question whether these vessels result from tumor cells invading lumen, from 'vasculogenic mimicry' of tumor cells, or from exposing underlying tumor cells due to apoptosis of endothelial cells. Despite of the internal reasons involved the existence of tumor cells in microvessel show momentous significance in metastasis and for the utilization of anti-angiogenic therapy. Recent evidence suggests that formation and maturation of new vessels are inconceivable complex and coordinated processes, requiring cascade reactions which consist of various receptors and ligands (Carmeliet and Jain, 2000). We now recognize several molecules involved in the regulation of 'angiogenic switch' such as vascular endothelial growth factor (VEGF), basic fibroblast growth factor, platelet-derived endothelial cell growth factor and angiopoietin. With the advent of specific antibodies to detect vascular endothelial cells, quantitative observation 
of tumor angiogenesis intensified. Concerning the relationship between angiogenesis and clinical outcome, ovarian cancer is one of the most conspicuous tumors. As a surrogate marker of angiogenesis, microvessel density has been proposed to be a prognostic indicator for human breast cancers in early 1990s (Weidner et al., 1992). Over the past two decades, studies reported that microvessel density is positively correlated to the clinicopathological factors of malignancies in breast cancer (Cao et al., 2013) as well as in prostate cancer (Muhammadnejad et al., 2013). To identify patients at early stage would be of great benefit, allowing for a more opportune surgery and effective chemotherapy to prolong survival and possibly predicting response rate of new drugs.

Most of the studies support positive correlations between microvessel density and overall survival (OS), progression free survival (PFS) or disease free survival (DFS). Some of the discrepancies may be elucidated by the influence of methodology such as antibody (e.g. CD34, CD105, CD31, VIII, von Willebrand factor or PECAM-1). Regardless of these intrinsic reasons, hotspot method is confirmed to be an independent prognostic variable (Zhang et al., 2006). Recommended methods for MVD count include Chalkley counting (Fox et al., 1994) and hot spots areas on a 400 or x200 field (e.g. 20 objective and 10 ocular, $0.785 \mathrm{~mm} 2$ per field).

Biomarkers such as MMP, E-cad and epididymis protein-4 have been confirmed to be associated with the prognosis of ovarian cancer (Lin et al., 2012; Peng et al., 2012; Li et al., 2013). Many observational researches have confirmed that MVD is inversely related to survival in ovarian cancer, while others yield opposite results. We examined the evidence explicitly, by conducting systematic literature review and a meta-analysis to discuss clinical relevance of MVD and survival of ovarian cancer patients.

\section{Materials and Methods}

\section{Search strategy}

A comprehensive search of online PubMed, Medline, EMBASE and Sciencedirect was done to identify all related articles focused on MVD and ovarian cancer. Published time was limited between 1990 and May 1st, 2012. Search strategy was designed as 'microvessel density', 'ovarian cancer', 'ovarian neoplasm', 'CD34' and 'angiogenesis'. Furthermore, references from eligible articles as well as reviews and editorials were reviewed manually to implement our search. We tried to avoid duplication of data by examining authors and medical center. When studies were published by the same medical center, journal with higher influence factor or larger sample size was chosen.

\section{Selection criteria}

We established included criteria as follow: (i) MVD count was performed by hotspots or Charkley count. (ii) The endpoints of investigation should include OS or PFS. (iii) Sufficient data for determining an estimate of Log-Hazard ratio (HR) and its 95\%CI. (iv) All observed patients must be diagnosed as ovarian cancer by pathology and enroll more than 30 patients. (v) Study population was divided into high MVD (or positive) and low MVD group (or negative) for survival analysis. (vi) Only articles written in English were included. Studies should be excluded: $(i)$ the same author or the same medical center with duplicate data, the article with higher influence factor was chosen. (ii) Follow-up was less than 3 year. (iii) Animal studies focused on subjects such as rabbit, BALB/c mouse or sheep.

Two authors (Lei He and Qiao Wang) independently evaluated titles and abstracts of all studies $(n=423)$ to decide whether full-text should be screened. Disagreement was resolved by consensus between two authors. For the condition of persistent disagreement, our professor made the final decision. We examined 73 full-text and pick up information with included and excluded criteria.

We did not set a predefined minimal duration of median follow-up. We failed to weigh each study by a quality score because no such score has been generally accepted in prognostic meta-analysis (Altman, 2001).

\section{Data extraction and analysis}

For every single study, we marked the results as 'positive' when higher MVD predicted poorer survival. In the sake for quantitative aggregation of OS, DFS and PFS, we measured MVD on survival by combining HR and its 95\% CI which was first published by Peto. We recorded the following information from eligible studies: first author/ year of publication, number of patients, FIGO stage, histology, cutoff value of MVD, types of survival analyses, HR and 95\% CI if available. According to the patients with or without pre-chemotherapy, we classified patients as 'baseline' and 'chemotherapy' subgroup. When more than one antibody was used to detect MVD, we recorded the HR and its $95 \%$ as independent data sets. HR and its 95\% CI was either directly collected from original article or calculated by survival (Parmar et al., 1998).

Heterogeneity between studies was evaluated by Chi-square test and expressed by I 2 index. As $\mathrm{I}^{2}>35 \%$ indicated heterogeneity, random effect (I-V heterogeneity) was used. Potential causes of heterogeneity were assessed by meta-regression analyses. We considered a worse survival when observed HR $>1$ for high MVD populations (Barraclough et al., 2011). This impact of high MVD on OS, DFS, and PFS was considered with statistical significance if the combined HR and its 95\%CI didn't overlap 1.

Publication bias was evaluated by Begg's Test, Egger's Test and Contour-enhanced funnel plot (presented by STATA 12.0). Publication bias was considered when $p<0.05$. Furthermore, contour-enhanced funnel plot is helpful to indicate regions of statistical significance, to interpret funnel plot and to identify whether the cause of asymmetry is due to factors such as variable study quality.

\section{Results}

\section{Eligible studies}

Four hundred twenty-two records were identified by primary search strategy. However, after screening of titles and abstracts, 324 original articles and 26 reviews 
Microvessel Density as a Prognostic Factor in Ovarian Cancer: a Systematic Review and Meta-analysis

were excluded because either of non-English, duplicate data, animal and cell studies or irrelevant to MVD and prognosis. Seventy-three full-texts were reviewed for detail. Fifty-one were further excluded for insufficient survival data or duplication. In two references (Gadducci et al., 2003; Raspollini et al., 2005), patients were overlapped; we picked up the larger sample size. Finally, 22 studies (Hollingsworth et al., 1995; Gasparini et al., 1996; Heimburg et al., 1999; Obermair et al., 1999; Shen et al., 2000; Nakayama et al., 2001; Hata et al., 2002; Ogawa et al., 2002; Raspollini et al., 2004; Chan et al., 2005; Goodheart et al., 2005; Gadducci et al., 2006; Ino et al., 2006; Taskiran et al., 2006; Palmer et al., 2007; Suhonen et al., 2007; Labiche et al., 2009; Rubatt et al., 2009; Han et al., 2010; Ferrero et al., 2011; Liu et al., 2012; Qin et al., 2012) fulfilled in this meta-analysis. The included 22 studies encompassed 1,918 ovarian cancer patients. 'Baseline' ( $n=1369)$ and 'chemotherapy' $(n=549)$ patients were enrolled in 17 and 5 studies, respectively. 'CD 34' $(n=1129)$ and 'other antibody' $(n=789)$ were enrolled in 9 and 13 studies. The main characteristics were presented in Table 1.

\section{Analysis of MVD on survival}

HRs for OS were available in 20 studies accounting for 1770 patients. The estimated HR for all studies indicated a significantly risk of death in patients with higher MVD

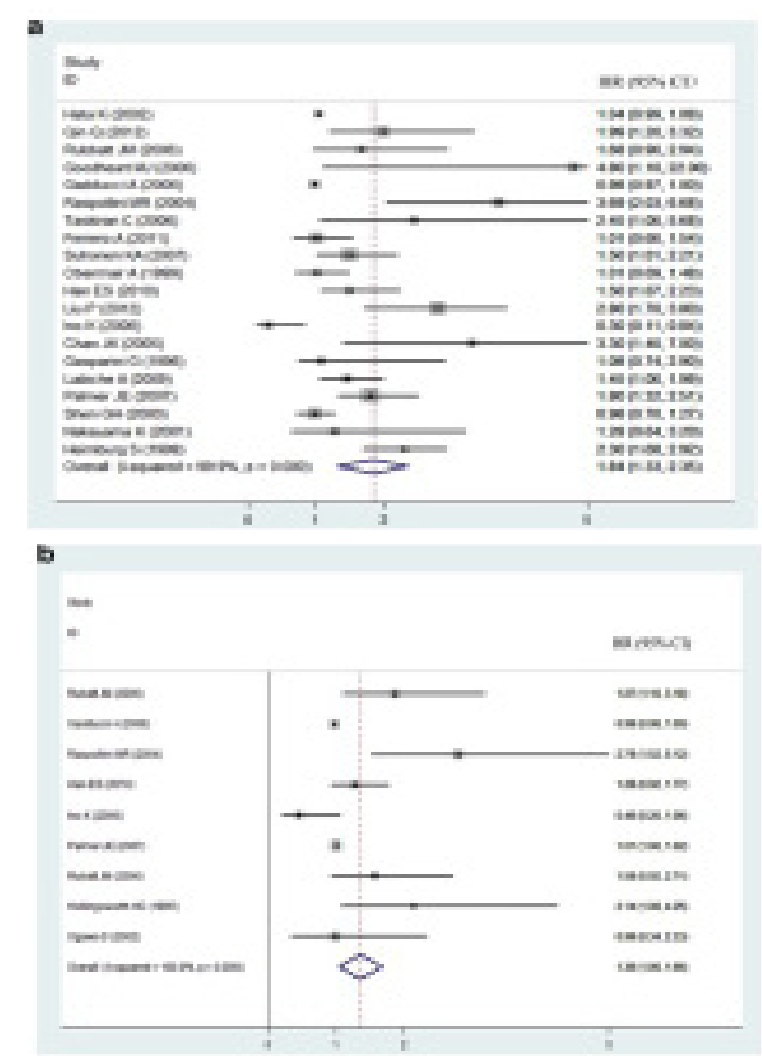

Figure 1. (a) The Association between High MVD and Overall Survival of Ovarian Cancer Stratified by HR Estimation. Meta-analysis of 20 eligible studies evaluating high MVD in overall survival. HR and its $95 \%$ CI for OS : 1.84 (1.33-2.35). (b) The association between high MVD and progression-free survival (PFS) of ovarian cancer. Meta-analysis of 8 eligible studies evaluating high MVD in PFS. HR and its 95\%CI for PFS : 1.36 (1.06-1.66)
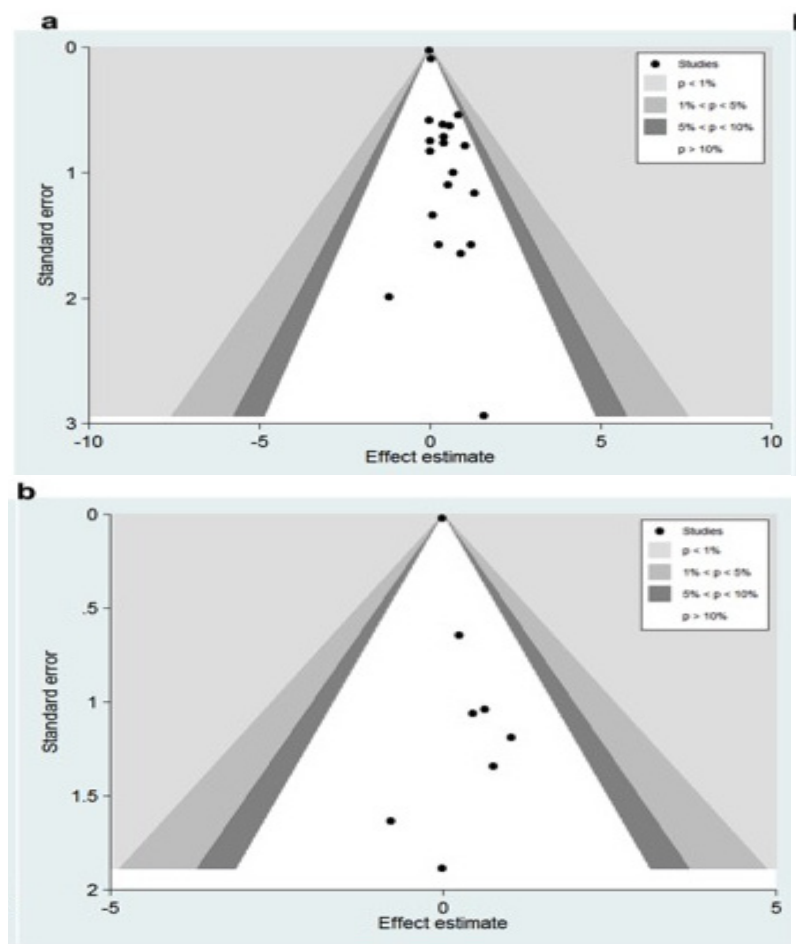

Figure 2. (a) Contour-enhanced Funnel Plot of 20 Eligible Studies Assessing the Influence of high MVD in OS of Ovarian Cancer Patients. (b) Contour-enhanced funnel plot of 8 eligible studies assessing the influence of high MVD in PFS of ovarian cancer patients

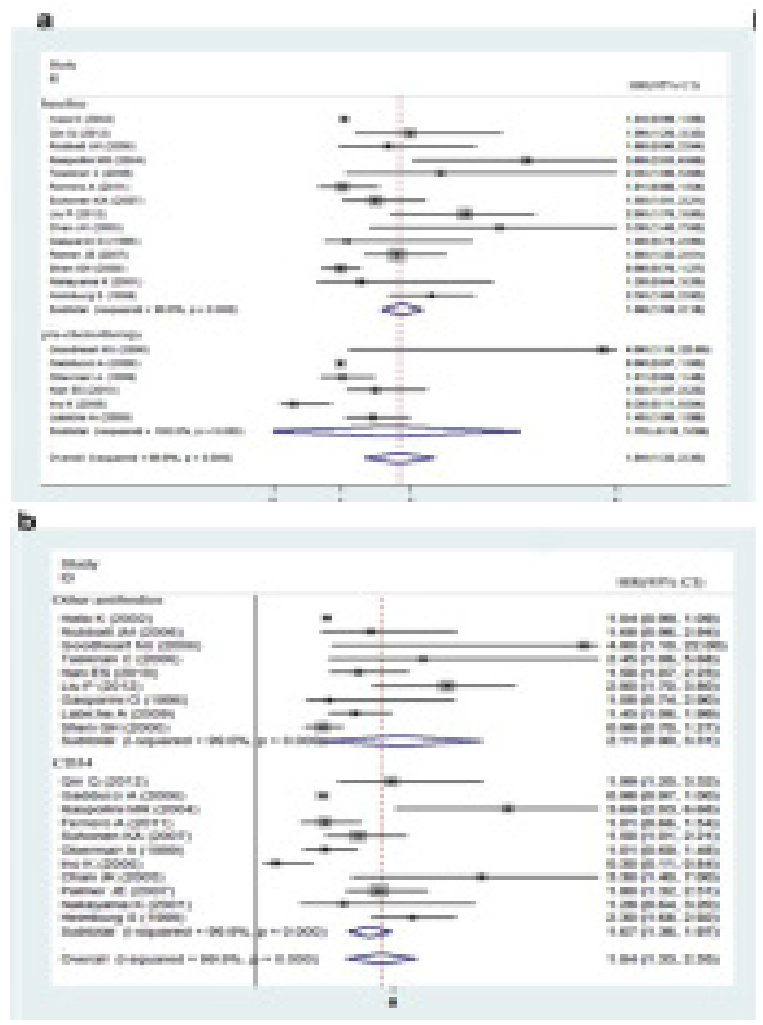

Figure 3. (a) Subgroup Analysis for Detecting Antibodies, HR=1.32 (0.82-1.82), for CD 34, HR and 95\% CI=1.67 (1.36-2.35); for other Antibodies, HR and $95 \% \mathrm{CI}=2.11(\mathbf{0 . 9 0 - 3 . 3 1 )}$. (b) Subgroup analysis for pre-chemotherapy, HR=1.70 (-0.18-3.59), for baseline, HR and $95 \% \mathrm{CI}=1.88(1.59-2.18)$ 
Table 1. Main Characteristic of 22 Included Studies

\begin{tabular}{|c|c|c|c|c|c|c|c|c|c|}
\hline Author/year & $\mathrm{N}$ & $\begin{array}{l}\text { FIGO stage } \\
\text { (N) }\end{array}$ & $\begin{array}{l}\text { Follow-up C } \\
\text { (Median) }\end{array}$ & Cutoff of MVD & Outcome & $\mathrm{HR}$ and $95 \% \mathrm{CI}$ & Antibody & stage & Results \\
\hline $\begin{array}{l}\text { Hata K } \\
(2002)\end{array}$ & 49 & $\begin{array}{l}\text { I-II(28) } \\
\text { III-IV(21) }\end{array}$ & 57 months & Mean number & OS & $1.04(0.99-1.09)$ & VIII & baseline & Positive \\
\hline $\begin{array}{l}\text { Qin Q } \\
(2012)\end{array}$ & 123 & III-IV & $?$ & $\begin{array}{l}75.8 \text { vessels/ } \\
\text { field } 200\end{array}$ & OS & $1.993(1.195-3.323)$ & CD34 & baseline & positive \\
\hline $\begin{array}{l}\text { Rubatt JM } \\
(2009)\end{array}$ & 50 & III & 158 months & Median value & $\begin{array}{l}\text { OS; } \\
\text { PFS }\end{array}$ & $\begin{array}{l}\text { CD105[OS:1.125(0.654- } \\
\text { 1.935);PFS:1.873(1.102- } \\
3.184)] \text {;CD31[OS: } 1.678 \\
(0.957-2.943) ; P F S: 1.578 \\
(0.918-2.711)]\end{array}$ & $\begin{array}{l}\text { CD31 } \\
\text { CD105 }\end{array}$ & baseline & $\begin{array}{l}\text { PFS: } \\
\text { positive }\end{array}$ \\
\hline $\begin{array}{l}\text { Goodheart MJ } \\
(2006)\end{array}$ & 77 & I & 74 months & 12 vessels/ field & OS & $4.8(1.1-22)$ & CD31 & $\begin{array}{l}\text { pre-chemo } \\
\text { therapy }\end{array}$ & positive \\
\hline $\begin{array}{l}\text { Gadducci A } \\
(2006)\end{array}$ & 101 & $\begin{array}{l}\text { III(90) } \\
\text { IV(11) }\end{array}$ & 65 months & $\begin{array}{l}40 \text { microvessels/ } \\
\text { field 200x } 0.74 \mathrm{~mm}^{2}\end{array}$ & $\begin{array}{l}\text { OS; } \\
\text { PFS }\end{array}$ & $\begin{array}{l}\text { PFS:0.988(0.978-0.999) } \\
\text { OS: } 0.985(0.973-0.998)\end{array}$ & CD34 & $\begin{array}{l}\text { pre-chemo- } \\
\text { therapy }\end{array}$ & positive \\
\hline $\begin{array}{l}\text { Raspollini MR } \\
\text { (2004) }\end{array}$ & 83 & III & 44.8 months & $\begin{array}{l}70 \text { microvessels/ } \\
\text { field }\end{array}$ & $\begin{array}{l}\text { OS; } \\
\text { PFS }\end{array}$ & $\begin{array}{l}\text { OS: } 3.69(2.03-6.68) \\
\text { PFS: } 2.79(1.52-5.12)\end{array}$ & CD34 & basaline & positive \\
\hline $\begin{array}{l}\text { Taskiran C } \\
(2006)\end{array}$ & 58 & $\begin{array}{l}\text { I-II(26) } \\
\text { III-IV(74) }\end{array}$ & 34 months & 12 vessels/field 200 & OS & $2.45(1.06-5.67)$ & CD105 & baseline & positive \\
\hline $\begin{array}{l}\text { Ferrero A } \\
(2011)\end{array}$ & 113 & $\begin{array}{l}\text { II }(7) \\
\text { III-IV(106) }\end{array}$ & 60 months & median & OS & $1.01(0.66-1.54)$ & CD34 & baseline & negative \\
\hline $\begin{array}{l}\text { Suhonen KA } \\
(2007)\end{array}$ & 175 & $\begin{array}{l}\text { I-II(58) } \\
\text { III-IV(117) }\end{array}$ & 23 months & Chalkley count: $8 \%$ & OS & $1.50(1.01-2.21)$ & CD34 & baseline & positive \\
\hline $\begin{array}{l}\text { Obermair A } \\
\text { (1999) }\end{array}$ & 63 & $\begin{array}{l}\text { I-II(25) } \\
\text { III-IV(38) }\end{array}$ & 6.75 years & $\begin{array}{l}10 \text { vessels } / 200 \\
\text { field } 0.25 \mathrm{~mm}^{2}\end{array}$ & OS & $1.01(0.69-1.48)$ & CD34 & $\begin{array}{l}\text { pre-chemo- } \\
\text { therapy }\end{array}$ & negative \\
\hline Han ES & 61 & $?$ & 43 month & Not clear & PFS; & OS:1.50(1.073-2.23) & CD31 & pre-chemo- & $\begin{array}{l}\text { OS: } \\
\text { positive }\end{array}$ \\
\hline (2010) & & & & & OS & PFS:1.276(0.918-1.774) & & therapy & $\begin{array}{l}\text { PFS: } \\
\text { negative }\end{array}$ \\
\hline $\begin{array}{l}\text { Liu P } \\
(2012)\end{array}$ & 166 & $\begin{array}{l}\text { I-II(14) } \\
\text { III-IV(152) }\end{array}$ & 42.8 months & $25 \%$ tumor cells & OS & $4.1(1.0-15.2)$ & CD105 & baseline & positive \\
\hline $\begin{array}{l}\text { Ino K } \\
(2006)\end{array}$ & 67 & $\begin{array}{l}\text { I-II(39) } \\
\text { III-IV(28) }\end{array}$ & 60 months & $\begin{array}{l}70 \text { vessels/ field } \\
400\end{array}$ & $\begin{array}{l}\text { OS; } \\
\text { PFS }\end{array}$ & $\begin{array}{l}\text { OS:0.30 (0.11 -0.84) } \\
\text { PFS: } 0.460 .20-1.06\end{array}$ & CD34 & baseline & negative \\
\hline $\begin{array}{l}\text { Chan JK/ } \\
(2005)\end{array}$ & 44 & III-IV & $>60$ months & $\begin{array}{l}11 \text { vessels/ field } \\
400\end{array}$ & OS & $3.3(1.4-7.0)$ & CD34 & baseline & positive \\
\hline $\begin{array}{l}\text { Hollingsworth } \\
\text { HC (1995) }\end{array}$ & 43 & III-IV & $60 \mathrm{~m}$ months & $\begin{array}{l}15 \text { vessels/ field } \\
400\end{array}$ & PFS & $2.14(1.08,4.25)$ & CD34 & $\begin{array}{l}\text { pre-chemo- } \\
\text { therapy }\end{array}$ & positive \\
\hline $\begin{array}{l}\text { Gasparini G } \\
(1996)\end{array}$ & 60 & III-IV & 46 months & $\begin{array}{l}48 \text { microvessels/ } \\
\text { field } 2000.74 \mathrm{~mm}^{2}\end{array}$ & OS & $\begin{array}{l}1.08(\mathrm{p}=0.21) \\
0.74-2.9\end{array}$ & CD31 & baseline & positive \\
\hline $\begin{array}{l}\text { Labiche A } \\
(2009)\end{array}$ & 204 & III-IV & 46 months & $?$ & OS & $1.45(1.06$ to 1.99$)$ & FVIII & $\begin{array}{l}\text { pre-chemo- } \\
\text { therapy }\end{array}$ & positive \\
\hline $\begin{array}{l}\text { Palmer JE } \\
(2007)\end{array}$ & 132 & $\begin{array}{l}\text { I-II(40) } \\
\text { III-IV(92) }\end{array}$ & $?$ & Median & $\begin{array}{l}\text { OS; } \\
\text { PFS }\end{array}$ & $\begin{array}{l}\text { OS:1.038(1.027-1.050) } \\
\text { PFS: } 1.010(1.005-1.016)\end{array}$ & CD34 & baseline & positive \\
\hline $\begin{array}{l}\text { Shen GH } \\
(2000)\end{array}$ & 64 & $\begin{array}{l}\text { I-II(37) } \\
\text { III-IV(27) }\end{array}$ & 31 months & $\begin{array}{l}40 \text { microvessels/field } \\
\text { OS } 2000.74 \mathrm{~mm}^{2}\end{array}$ & $\begin{array}{c}\text { OS:0.98 } \\
(0.10- \\
1.86)\end{array}$ & FVIII & baseline & negative & \\
\hline $\begin{array}{l}\text { Nakayama K } \\
(2001)\end{array}$ & 42 & $\begin{array}{l}\text { I-II(16) } \\
\text { III-IV(26) }\end{array}$ & $?$ & Median value & OS & $1.28(0.64-3.20)$ & CD34 & baseline & negative \\
\hline $\begin{array}{l}\text { Ogawa S } \\
(2002)\end{array}$ & 105 & $\begin{array}{l}\text { I-II(8) } \\
\text { III-IV(49) }\end{array}$ & $>60$ months & $\begin{array}{l}70 \text { microvessels/ } \\
\text { field } 2000.75 \mathrm{~mm}^{2}\end{array}$ & PFS & $0.99(0.34-2.33)$ & CD34 & baseline & positive \\
\hline $\begin{array}{l}\text { Heimburg S } \\
\text { (1999) }\end{array}$ & 38 & $\begin{array}{l}\text { I-II(7) } \\
\text { III-IV(31) }\end{array}$ & $?$ & $\begin{array}{l}40 \text { microvessels/ } \\
\text { field } 200\end{array}$ & OS & $2.3(1.68-2.92)$ & CD34 & baseline & positive \\
\hline
\end{tabular}

(HR=1.84,95\%CI: 1.33-2.35, random-effects, Figure.1a). Since the heterogeneity among studies was significant $\left(\mathrm{I}^{2}=99.9 \%, p=0.000\right)$, random effect was selected. Twenty studies yielded a Begg's and Egger's test which $p=0.697$ and $p=0.233$ respectively. Furthermore, confunnel plot (contour-enhanced funnel plot) was undertaken which also indicates absence of publication bias (Figure 2a).

HRs for PFS were available in 9 studies accounting for 747 patients. In one study (Rubatt et al., 2009), more than one HR was extracted because multi-antibodies were used to detect MVD and HRs were reported accordingly. The estimated HR for all studies indicated a significantly risk of disease progression in patients with higher MVD
(HR=1.36,95\%CI: 1.06-1.66, random-effects, Figure 1b). Since the heterogeneity among studies was significant (I2 $=100 \%, p=0.000)$, random effect was selected. Nine studies yielded a Begg's and Egger's test which $p=0.10$ and $p=0.12$ respectively. Furthermore, confunnel plot (contour-enhanced funnel plot) was undertaken which also indicates absence of publication bias (Figure 2b).

\section{Influence of sampling time point and antibody}

The prognostic value of MVD for OS was significant in the 'baseline' subgroup ( $\mathrm{HR}=1.88,95 \% \mathrm{CI}$ : 1.59-2.18), while it was not significant in 'chemotherapy' subgroup $(\mathrm{HR}=1.70,95 \% \mathrm{CI}:-0.18-3.59$, Fig. 3a) which the 95\%CI 
Microvessel Density as a Prognostic Factor in Ovarian Cancer: a Systematic Review and Meta-analysis did not cross the threshold of 1.0. The prognostic value of MVD for OS was significant in the 'CD 34' subgroup (HR=1.67,95\%CI: 1.36-1.97), while it was not significant in 'other antibodies' subgroup (HR=2.11, 95\% CI: -0.90 3.31 , Figure $3 b$ ) which the $95 \%$ CI did not cross the threshold of 1.0 .

\section{Discussion}

The present meta-analysis showed that the prognostic significance of high MVD vary substantially between studies. We confirmed that alternations of MVD were predictive of mortality and progression in ovarian cancer. Owing to limited eligible studies, our studies failed to evaluate the influence of MVD on recurrence. Further, results were also shown in subgroup analyses for patients with or without pre-chemotherapy, as well as different antibodies. CD34-MVD has an effect on predicting prognosis while other antibodies-MVD fails to indicate stronger relationship with prognosis. Moreover, subgroup analysis of patients with pre-chemotherapy does not predict clinical outcome. This is the first meta-analysis of published studies to evaluate the association between MVD count and prognosis in ovarian cancer. However, all eligible studies in our meta-analysis were observational studies, more prone to bias than randomized controlled trails (Grimes and Schulz, 2002). Hence, these conclusions should be interpreted with caution.

Our study was carried out using published results; there are some bias of our meta-analysis which are the same as the bias reported in the meta-analysis of relations between epididymis protein-4 and prognosis in ovarian cancer (Lin et al., 2012) . We did not look for unpublished trails because our study required data available in fullpublished articles. And the cut off values for MVD+ were different, some studies used median value, some studies used $40 \mathrm{microvessel} /$ field $2000.74 \mathrm{~mm}^{2}$ or other values. These distinctions are responsible for the difficulty in determining a standard cut off in clinical practice. Another variability of bias is related to the language selection which positive results are more favorable in English, whereas negative results tend to be reported in native language (Egger et al., 1997). Moreover, methodology for extrapolating HR might be a potential bias in HR estimates. For some studies without HR and 95\% CI directly, we need to obtain data from survival curves, assuming that censored observations were well distributed. Finally, it is inevitable that all the included articles have difference in patient's baseline status such as age, tumor size, lymph node status, chemotherapy strategy of prechemotherapy, antibodies for MVD detecting and duration of follow-up, even the counting method of MVD.

Despite its excellence as a prognostic factor in untreated ovarian cancer, MVD has not been shown to be an indicator to guide antiangiogenic treatment or monitor response of chemotherapy (Hlatky et al., 2002). Our analysis also showed that MVD failed to predict survival after initial chemotherapy. It is widely hypothesized that tumors with high MVD are superior candidates of antioangiogenic therapies, while tumors with low MVD are regarded as a poor candidate (Wesseling et al., 1998). However, evidence revealed that bladder tumors with low MVD were found to be more effective by low-dose angiostatin than those tumors with high MVD (Beecken et al., 2001). Thus, MVD is not a useful tool for stratifying patients for clinical trials.

Undoubtedly, our study indicated that the choice of antibody for MVD detecting was crucial for conclusion. There are 13 studies in our meta-analysis using CD34 as an endothelial marker, 9 studies using other markers such as factor VIII (FVIII), CD31, and CD105. Of the 3 studies using FVIII, results indicated poor prognostic influence. Factor VIII is one of the first markers used for staining MVD, but not all endothelial cells express FVIII. On the other hand, FVIII is also expressed in lymphatic endothelium, and platelets leading to crossreactivity with non-endothelial cells. CD34 is a highly glycosylated transmembrane protein which is expressed on immature hematopoietic cells as well as on luminal endothelial cells. It was reported that CD34 display a better sensitivity and specificity than FVIII for endothelial cells induced by tumor angiogenesis (Tanigawa et al., 1996). CD32 is also a transmembrane glycosylated protein which is expressed both in mature and immature vascular endothelium. During cellular differentiation, CD31 is also expressed which results in cross-react with neutrophils, lymphatic B cells and platelets. Consequently, CD34 and CD31-MVD counts are approximately $30 \%$ higher than FVIII (Uzzan et al., 2004). The chemical structure of CD 31 and CD 34 are resembled, but CD34 is more stable than CD31 which cross-react with fibroblasts and plasma (Leek, 2001). Although optimal marker for MVD has not been established, we recommend using CD34 for MVD in future studies.

To conclude, a systematic review suggested a poor overall survival and progression-free survival of high MVD in patients with ovarian cancer. Data are insufficient to determine its role in disease-free survival. To achieve clinical utility of MVD in ovarian cancer, more highquality interventional researches are acquired. Formal process for patients baseline status, MVD detecting and MVD count should be followed systematically before introducing into clinical practice.

\section{References}

Altman DG (2001). Systematic reviews of evaluations of prognostic variables. $B M J, \mathbf{3 2 3}, 224-8$.

Barraclough H, Simms L, Govindan R (2011). Biostatistics primer: what a clinician ought to know: hazard ratios. $J$ Thorac Oncol, 6, 978-82.

Bast RC, Jr., Hennessy B, Mills GB (2009). The biology of ovarian cancer: new opportunities for translation. Nat Rev Cancer, 9, 415-28.

Beecken WD, Fernandez A, Joussen AM, et al (2001). Effect of antiangiogenic therapy on slowly growing, poorly vascularized tumors in mice. J Natl Cancer Inst, 93, 382-7.

Cao F, Hu YW, Li P, et al (2013). Lymphangiogenic and angiogenic microvessel density in Chinese patients with gastric carcinoma: correlation with clinicopathologic parameters and prognosis. Asian Pac J Cancer Prev, 14, 4549-52.

Carmeliet P (2000). Mechanisms of angiogenesis and arteriogenesis. Nature Med, 6, 389-95. 
Carmeliet P, Jain RK (2000). Angiogenesis in cancer and other diseases. Nature, 407, 249-57.

Chan JK, Magistris A, Loizzi V, et al (2005). Mast cell density, angiogenesis, blood clotting, and prognosis in women with advanced ovarian cancer. Gynecol Oncol, 99, 20-5.

Egger M, Zellweger-Zahner T, Schneider M, et al (1997). Language bias in randomised controlled trials published in English and German. Lancet, 350, 326-9.

Ferrero A, Dompe D, Ravarino N, et al (2011). Angiogenesis and molecular markers in advanced epithelial ovarian cancer: a retrospective study. Gynecol Oncol, 123, 301-7.

Folkman J (1971). Tumor angiogenesis: therapeutic implications. N Engl J Med, 285, 1182-6.

Fox SB, Leek RD, Smith K, et al (1994). Tumor angiogenesis in node-negative breast carcinomas-relationship with epidermal growth factor receptor, estrogen receptor, and survival. Breast Cancer Res Treat, 29, 109-16.

Gadducci A, Ferrero A, Cosio S, et al (2006). Intratumoral microvessel density in advanced epithelial ovarian cancer and its use as a prognostic variable. Anticancer Res, 26, 3925-32.

Gadducci A, Viacava P, Cosio S, et al (2003). Intratumoral microvessel density, response to chemotherapy and clinical outcome of patients with advanced ovarian carcinoma. Anticancer Res, 23, 549-56.

Gasparini G, Bonoldi E, Viale G, et al (1996). Prognostic and predictive value of tumour angiogenesis in ovarian carcinomas. Int J Cancer, 69, 205-11.

Goodheart MJ, Ritchie JM, Rose SL, et al (2005). The relationship of molecular markers of p53 function and angiogenesis to prognosis of stage I epithelial ovarian cancer. Clin Cancer Res, 11, 3733-42.

Grimes DA, Schulz KF (2002). Bias and causal associations in observational research. Lancet, 359, 248-52.

Han ES, Burger RA, Darcy KM, et al (2010). Predictive and prognostic angiogenic markers in a gynecologic oncology group phase II trial of bevacizumab in recurrent and persistent ovarian or peritoneal cancer. Gynecol Oncol, 119, 484-90.

Hata K, Yoshida M, Maruyama R, et al (2002). Prognostic significance of ultrasound derived intratumoral peak systolic velocity in epithelial ovarian cancer. Ultrasound Obstet Gynecol, 20, 186-91.

Heimburg S, Oehler MK, Papadopoulos T, et al (1999). Prognostic relevance of the endothelial marker CD 34 in ovarian cancer. Anticancer Res, 19, 2527-9.

Hlatky L, Hahnfeldt P, Folkman J (2002). Clinical application of antiangiogenic therapy: microvessel density, what it does and doesn't tell us. J Natl Cancer Inst, 94, 883-93.

Hollingsworth HC, Kohn EC, Steinberg SM, et al (1995). Tumor angiogenesis in advanced stage ovarian carcinoma. Am J Pathol, 147, 33-41.

Ino K, Shibata K, Kajiyama H, et al (2006). Angiotensin II type 1 receptor expression in ovarian cancer and its correlation with tumour angiogenesis and patient survival. $\mathrm{Br} J$ Cancer, 94, 552-60.

Labiche A, Elie N, Herlin P, et al (2009). Prognostic significance of tumour vascularisation on survival of patients with advanced ovarian carcinoma. Histol Histopathol, 24, 425-35.

Leek RD (2001). The prognostic role of angiogenesis in breast cancer. Anticancer Res, 21, 4325-31.

Li LN, Zhou X, Gu Y, et al (2013). Prognostic value of MMP-9 in ovarian cancer: a meta-analysis. Asian Pac J Cancer Prev, 14, 4107-13.

Lin JY, Qin JB, Li XY, et al (2012). Diagnostic value of human epididymis protein 4 compared with mesothelin for ovarian cancer: a systematic review and meta-analysis. Asian Pac J Cancer Prev, 13, 5427-32.

Liu P, Sun YL, Du J, et al (2012). CD105/Ki67 coexpression correlates with tumor progression and poor prognosis in epithelial ovarian cancer. Int J Gynecol Cancer, 22, 586-92.

Muhammadnejad S, Muhammadnejad A, Haddadi M, et al (2013). Correlation of microvessel density with nuclear pleomorphism, mitotic count and vascular invasion in breast and prostate cancers at preclinical and clinical levels. Asian Pac J Cancer Prev, 14, 63-8.

Nakayama K, Kanzaki A, Takebayashi Y, et al (2001). Different features of angiogenesis between ovarian and breast carcinoma. Cancer Lett, 170, 161-7.

Obermair A, Wasicky R, Kaider A, et al (1999). Prognostic significance of tumor angiogenesis in epithelial ovarian cancer. Cancer Lett, 138, 175-82.

Ogawa S, Kaku T, Kobayashi H, et al (2002). Prognostic significance of microvessel density, vascular cuffing and vascular endothelial growth factor expression in ovarian carcinoma: a special review for clear cell adenocarcinoma. Cancer Lett, 176, 111-8.

Palmer JE, Sant Cassia LJ, Irwin CJ, et al (2007). Prognostic value of measurements of angiogenesis in serous carcinoma of the ovary. Int J Gynecol Pathol, 26, 395-403.

Parmar MK, Torri V, Stewart L (1998). Extracting summary statistics to perform meta-analyses of the published literature for survival endpoints. Stat Med, 17, 2815-34.

Peng HL, He L, Zhao X (2012). Association of reduced immunohistochemical expression of E-cadherin with a poor ovarian cancer prognosis - results of a meta-analysis. Asian Pac J Cancer Prev, 13, 2003-7.

Qin Q, Sun Y, Fei M, et al (2012). Expression of putative stem marker nestin and CD133 in advanced serous ovarian cancer. Neoplasma, 59, 310-5.

Raspollini MR, Amunni G, Villanucci A, et al (2005). Microvessel density in ovarian carcinoma: computer image analysis in patients with shorter and longer survival. Int J Gynecol Cancer, 15, 844-9.

Raspollini MR, Amunni G, Villanucci A, et al (2004). Prognostic significance of microvessel density and vascular endothelial growth factor expression in advanced ovarian serous carcinoma. Int J Gynecol Cancer, 14, 815-23.

Risau W (1997). Mechanisms of angiogenesis. Nature, 386, 671-4.

Rubatt JM, Darcy KM, Hutson A, et al (2009). Independent prognostic relevance of microvessel density in advanced epithelial ovarian cancer and associations between CD31, CD105, p53 status, and angiogenic marker expression: a gynecologic oncology group study. Gynecol Oncol, 112, 469-74.

Shen GH, Ghazizadeh M, Kawanami O, et al (2000). Prognostic significance of vascular endothelial growth factor expression in human ovarian carcinoma. Br J Cancer, 83, 196-203.

Suhonen KA,Anttila MA, Sillanpaa SM, et al (2007). Quantification of angiogenesis by the Chalkley method and its prognostic significance in epithelial ovarian cancer. Eur J Cancer, 43, 1300-7.

Tanigawa N, Amaya H, Matsumura M, et al (1996). Extent of tumor vascularization correlates with prognosis and hematogenous metastasis in gastric carcinomas. Cancer Res, 56, 2671-6.

Taskiran C, Erdem O, Onan A, et al (2006). The prognostic value of endoglin (CD105) expression in ovarian carcinoma. Int $J$ Gynecol Cancer, 16, 1789-93.

Uzzan B, Nicolas P, Cucherat M, et al (2004). Microvessel density as a prognostic factor in women with breast cancer: a systematic review of the literature and meta-analysis. Cancer Res, 64, 2941-55.

Weidner N, Folkman J, Pozza F, et al (1992). Tumor angiogenesis: a new significant and independent prognostic indicator in early-stage breast carcinoma. J Natl Cancer Inst, 84, 1875-87.

Wesseling P, van der Laak JA, Link M, et al (1998). Quantitative analysis of microvascular changes in diffuse astrocytic neoplasms with increasing grade of malignancy. Hum Pathol, 29, 352-8.

Yancopoulos GD, Davis S, Gale NW, et al (2000). Vascular-specific growth factors and blood vessel formation. Nature, 407, 242-8.

Zhang SC, Hironaka S, Ohtsu A, et al (2006). Computer-assisted analysis of biopsy specimen microvessels predicts the outcome of esophageal cancers treated with chemoradiotherapy. Clin Cancer Res, 12, 1735-42. 